\title{
PERTIMBANGAN HAKIM DALAM MENETAPKAN GANTI RUGI AKIBAT PUTUSAN PRA PERADILAN (Studi Kasus di Pengadilan Negeri Padangsidimpuan)
}

\author{
Fajar Fadli \\ Universitas Muhammadiyah Tapanuli Selatan, \\ Email : fajar.fadli@um-tapsel.ac.id
}

\begin{abstract}
Abstrak
Dalam penelitian ini yang menjadi masalah adalah, pertama, apakah dasar atau alasan bagi hakim dalam menetapkan ganti rugi sebagai akibat putusan praperadilan? Kedua, apakah yang menghambat pemberian ganti rugi terhadap putusan praperadilan khususnya setelah berlakunya KUHAP? Metode yang digunakan adalah metode penelitian pustaka (library reseaech) dan lapangan (field research), dengan pengumpulan data dilakukan dengan interview (wawancara) dan studi dokumentasi.

Setelah data dianalisa dengan menggunakan teknik pengujian hipotesa berdarkan metode induksi dan deduksi. Maka dapat diperoleh hasil bahwa dasar atau alasan bagi hakim dalam menetapkan ganti rugi sebagai akibat putusan praperadilan adalah kerugian moral atau material yang diderita oleh tersangka/terdakwa karena akibat upaya paksa yang dibuktikan berdasarkan keyakinan hakim. Kemudian pada bahwa pada dasarnya sebagai penghambat kurangnya pelaksanaan ganti rugi dalam prakteknya, adalah disebabkan belum adanya bentuk secara khusus yang mengatur ketentuan proses pengajuan tuntutan ganti rugi.

Kata Kunci : Ganti Rugi, Putusan, Pra Peradilan
\end{abstract}

\section{PENDAHULUAN}

\section{Latar Belakang Masalah}

Pemberian ganti rugi bagi seseorang tidak lain disebabkan adanya tindakantindakan yang kurang atau bertentangan dengan prosedur aturan Perundangundangan yang berlaku, tujuannya tidak terlepas pula dengan perlindungan hak-hak azasi manusia di dalam hukum.

Masalah hak-hak azasi manusia di dalam hukum apalagi setelah diberlakukannya Undang-Undang Nomor 8 Tahun 1981 tentang Kitab Undang-Undang Hukum Acara Pidana, untuk menggantikan HIR sebagai hukum acara pidana produk Kolonial Belanda kiranya masalah penegak dan perlindungan hak-hak azasi manusia telah dijadikan sebagai salah satu landasan tujuan operasional yang harus selalu menjadi pertimbangan pada setiap melakukan proses pemeriksaan, baik saat pemeriksaan pendahuluan sampai pada pemeriksaan di sidang pengadilan.

Berdasarkan uraian di atas maka jelaslah bahwasanya masalah penegakan dan perlindungan hak-hak azasi manusia sudah ditentukan sebagai titik sentral dalam memeriksa dan menyelesaikan suatu kasus tindak pidana. Dengan pengertian lain bahwa sekalipun tujuan tindakan penegakan hukum untuk mempertahankan dan melindungi kepentingan masyarakat, jelas dengan landasan operasional KUHAP yang disebut di atas penegakan hukum tidak boleh sampai mengorbankan kepentingan hak dan martabat manusia, apalagi seseorang tersebut sedang berada dalam kedudukan sebagai tersangka atau terdakwa di sidang pengadilan.

Demikianlah masalah perlindungan hak-hak azasi manusia bilamana dikaitkan setelah berlakunya KUHAP, jelas di dalamnya ditentukan bahwa setiap tindakan hukum yang bersifat paksa terhadap seseorang tidak dapat dilakukan secara sewenang-wenang. Dan sebaliknya diharapkan harus dapat memberikan perlindungan terhadap hak asasi manusia khususnya kepada para pencari keadilan, atau dengan kata lain lagi pelaksanaannya diperlukan adanya keseluruhan atau keseimbangan antara kepentingan keadilan 


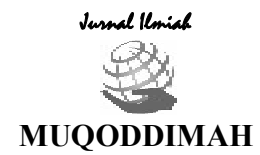

selaku individu dengan kepentingan anggota masyarakat. Apabila kita nanti dalam perkembangan prakteknya sekarang ini khususnya di wilayah hukum Pengadilan Negeri Padangsidimpuan ini, kiranya pelaksanaannya untuk melakukan tindakan saat pemeriksaan pendahuluan dalam mencari serta mengumpulkan keteranganketerangan dari tersangka/terdakwa. Adakalanya upaya paksa yang diberikan Undang-Undang sebagai suatu wewenang penyidik, dapat dikatakan terlalu berlebihan dan tidak jarang tindakan paksa tersebut sempat menimbulkan efek yang tidak baik. Sehingga sebagai upaya perlindungan bagi para tersangka/terdakwa untuk mengajukan keberatan atas tindakan tersebut, diajukanlah suatu peradilan ganti rugi lewat sidang peradilan. Namun sebagaimana terlihat perkembangan penggunaan lembaga peradilan, kiranya masalah ganti rugi yang dimohonkan di dalamnya juga masih jauh dari yang diharapkan dan apa yang dicitacitakan lewat KUHAP justru semakin adanya pengekangan dan pembatasan-pembatasan hak-hak azasi manusia. Maka

berdasarkan uraian di atas, penulis memilih judul penelitian yaitu: "Pertimbangan Hakim Dalam Menetapkan Ganti Rugi Akibat Putusan Pra Peradilan (Studi Kasus Di Pengadilan Negeri Padangsidimpuan)"

\section{Perumusan Masalah}

Dalam salah satu literatur tentang penelitian ilmiah disebutkan bahwa yang dimaksud dengan permasalahan adalah" Kalau ada kesenjganan (gap) antara das sollen dan das sain, ada perbedaan antara yang seharusnya dan apa yang ada dalam kenyataan, antara apa yang diperlukan dan apa yang tersedia antara harapan dan kenyataan, dan yang sejenis dengan itu".(Sumadi Suryabrata,1993:66)

Permasalahan yang diangkat dalam penelitian ini, masalah pemberian ganti rugi sebagai akibat putusan praperadilan masih menimbulkan masalah yang memerlukan perhatian, tentang bagaimana sehingga mempu memberikan perlindungan terhadap hak-hak asasi manusia dari upaya yang dilakukan aparat, atas dasar itu penulis mengangkat permasalahan adalah sebagai berikut di bawah ini:

1. Apakah dasar atau alasan bagi hakim dalam menetapkan ganti rugi sebagai akibat putusan pra peradilan?

2. Apakah yang menghambat pemberian ganti rugi terhadap putusan pra peradilan khususnya setelah berlakunya KUHAP?

\section{Tujuan Penelitian}

Tujuan penelitian ini adalah ini:

1. Untuk mengetahui dasar atau alasan bagi hakim dalam menetapkan ganti rugi sebagai akibat putusan praperadilan?

2. Untuk mengetahui apakah yang menghambat pemberian ganti rugi terhadap putusan praperadilan khususnya setelah berlakunya KUHAP.

\section{Manfaat Penelitian}

Adapun yang menjadi kegunaan penelitian ini adalah sebagai berikut :

a. Menambah pengalaman peneliti yang mana penelitian ini kelak dapat digunakan oleh pihak-pihak lain

b. Sebagai masukan bagi lembaga penegak hukum, baik Polisi maupun Pengadilan Negeri Padangsidimpuan tentang pelaksanaan pemberian ganti rugi akibat dikabulkannya gugatan praperadilan oleh hakim

\section{Kajian Teoritis}

\section{Latar Belakang dan Pengertian Ganti Rugi}

Berbicara tentang masalah pemberian ganti rugi bagi seseorang melalui penetapan sidang praperadilan tidak lain merupakan perwujudan dari dianutnya asas "presumption of innocence" dalam aturan hukum acara pidana di Indonesia,

Adapun kekuatan azas tersebut setelah berlakunya Undang-Undang Hukum Acara Pidana Nomor 8 Tahun 1981 (KUHAP) hal ini secara tegas telah digariskan sebagai azas fundamental bagi perlindungan hak-hak tersangka ataupun terdakwa, pelaksanaan peradilan harus dilandaskan atas ketentuan hukum, sebagaimana dikatakan dalam Pasal 1 ayat 3 Undang-Undang Dasar 1945 bahwa: 
"Negara Indonesia adalah negara hukum". (Undang-Undang Dasar 1945,2008:6)

Mengingat pentingnya mencari serta menemukan kebenaran atas suatu fakta peristiwa yang terjadi, oleh hukum acara membenarkan pemeriksaan dengan pengurangan-pengurangan hak-hak tersangka atau terdakwa. Seperti halnya melakukan penangkapan, penahanan serta tindakan-tindakan lainnya yang mengurangi kebebasan manusia. Oleh sebab itulah untuk mengawasi wewenang pengurangan kebebasan dan hak azasi tersebut harus berlandaskan kepada prinsip-prinsip hukum, maka ditentukan suatu lembaga dalam proses peradilan sebagai wadah untuk memeriksa tindakan paksa yang dilakukan oleh aparat. dikenal sebagai "Praperadilan" yaitu suatu lembaga yang mempunyai ciri, eksistensi atau keberadaannya merupakan pemberian wewenang baru kepada Pengadilan Negeri. Untuk lebih jelasnya lembaga ini sebagaimana diuraikan dalam Pasal 1 butir 10 Kitab Undang-Undang Hukum Acara Pidana, dalam ketentuan pasal 1 butir 10 Kitab Undang-Undang Hukum Acara Pidana tersebut diatur bagaimana upaya yang dapat dilakukan seseorang pelaku tindak pidana melindungi dirinya. Yang mana dengan dilakukannya penangkapan, penahanan serta penghentian penyidikan dan juga penuntutan, seseorang dapat mengajukan pemeriksaan kehadapan sidang pengadilan untuk meminta kebenaran apakah tindakan yang dilakukan atas dirinya syah berdasarkan Undang-Undang atau tidak. Kemudian lewat pemeriksaan praperadilan untuk membuktikan upayaupaya paksa yang dilakukan penyidik atas diri tersangka, juga bagi para tersangka memungkinkan untuk meminta ganti rugi bilamana ia merasa ada tindakan-tindakan paksa yang sempat merugikan dirinya. Hal ini sebagaimana dikatakan Loebby Loqman, bahwa:"Kesalahan bagaimanapun juga dapat timbul pada semua tingkat pemeriksaan dalam suatu sistim peradilan pidana, dan korban kesalahan tersebut haruslah mendapat ganti rugi, dan setiap keadilan apalagi yang menyangkut kehilangan kemerdekaan seseorang haruslah dikembalikan kepada suatu keadaan yang adil dengan memberikan sejumlah ganti kerugian, hal ini haruslah dilakukan demi hukum. (2002:72)

Adapun yang menjadi dasar hukum bagi pengadilan untuk memberikan ganti rugi, hal ini sebagaimana tercantum dalam Pasal 9 Undang-undang Nomor 48 Tahun 2009. Dalam penentuan KUHAP ditegaskan bahwa maksud atau pengertian ganti rugi ini, secara jelas disebutkan dalam Bab I Pasal 1 butir ke-22 yang memberi batasan sebagai berikut: "Ganti kerugian adalah hak seorang untuk mendapat penuhan atas tuntutannya yang berupa imbalan sejumlah uang karena ditangkap, ditahan, dituntut ataupun diadili tanpa alasan yang berdasarkan Undangundang atau karena kekeliruan mengenai orangnya atau hukum yang diterapkan menurut cara yang diatur dalam UndangUndang". (KUHAP,1994:8)

Kemudian dari ketentuan pasal tersebut di atas juga dapat digolongkan bahwasanya ganti rugi terbagi dua:

a. Ganti rugi atas tuntutan (ex) pelanggaran atas hukum pidana

b. Ganti rugi atas tuntutan pihak penderita (si korban) karena terjadinya pelanggaran hukuman atau pemidanaan. (Soedirjo,1986:17)

Dari rumusan Soedirdjo, tersebut kiranya ganti rugi yang dimaksudkanya adalah sebagai akibat dari tuntutan ganti rugi sebagaimana dimaksudkan dalam ketentuan sidang praperadilan. Oleh sebab itu M. Yahya Harahap, mengkategorikan masalah ganti rugi ke dalam tiga bagian, yaitu:

a. Ganti kerugian karena seseorang ditangkap, ditahan ataupun diadili tanpa alasan yang berdasarkan undangundang atau kekeliruan mengenai penentuan orangnya atau salah menerapkan hukumnya.

b. Ganti rugi atas alasan penghentian penyidikan dan penghentian penuntutan.

c. Ganti kerugian yang ditimbulkan oleh tindak pidana itu sendiri.(M.Yahya Harahap,1999:512) 
Ganti rugi yang dimaksudkan dalam penelitian ini adalah menyangkut ganti rugi yang berkaitan dengan tindakan pada pemeriksaan pendahuluan dan penuntutan. Jadi tidak termasuk dalam ganti rugi akibat dari suatu tindak pidana, sebagaimana digolongkan dalam sub $\mathrm{c}$ di atas. Atau dengan kata lain adalah yang berkaitan dengan: " Adanya perbuatan yang menyebabkan terjadinya kerugian, yang dipihak lain menimbulkan kewajiban untuk mengganti kerugian tersebut. Dengan demikian kita berbicara mengenai soal tanggung jawab atas perbuatan yang bertentangan dengan hokum".(Joko Prakoso, 1989:98)

Gambaran perbuatan sebagaimana dimaksudkan dalam uraian tersebut dalam hukum perdata secara jelas ditentukan pada pasal 1365 Kitab Undang-Undang Hukum Perdata yang berbunyi: "Tiap perbuatan melanggar hukum yang membawa kerugian kepada seorang lain, mewajibkan orang yang kerana kesalahannya menerbitkan kerugian itu, mengganti kerugian tersebut".(R. Subekti dan R Tjitrosudibio,2001:21)

Menanggapi ketentuan pasal 1365 Kitab Undang-Undang Hukum Perdata tersebut di atas adalah diartikan dalam pengertian yang luas, seperti berikut dibawah ini: Bahwa perbuatan itu mengakibatkan kegoncangan dalam neraca keseimbangan dalam masyarakat dan kegoncangan itu tidak hanya terdapat apabila dilanggar secara (langsung) melainkan juga apabila peraturan kesusilaan, sopan santun dalam masyarakat dilanggar secara (langsung).(Wirjono Prodjodikro,1980:12)

\section{Beberapa Alasan Permintaan Ganti Rugi Dalam Sidang Pengadilan}

Mengenai alasan untuk meminta ganti rugi dalam proses peradilan pidana hal ini telah jelas ditentukan dalam Undang-Undang Hukum Acara Pidana (UU Nomor 8 Tahun 1981), yakni seperti tersebut pada Pasal 82 ayat (4) KUHAP: "Ganti kerugian dapat diminta terhadap hal-hal yang meliputi sebagaimana dimaksud dalam Pasal 77 dan Pasal 95 KUHAP”. (KUHAP,1994:38)
Dengan pengertian dari isi pasal tersebut di atas kiranya dapat disimpulkan bahwasanya, seseorang yang ingin mengajukan ganti rugi melalui sidang praperadilan tidak boleh bertentangan dnegan apa yang telah disebut secara limitatif dalam Pasal 77 dan 95 KUHAP. Karenanya jika dibandingkan dengan masalah ganti rugi yang terdapat dalam pasal 1365 Kitab Undang-Undang Hukum Perdata, jelas ganti rugi dalam ketentuan Kitab Undang-Undang Hukum Acara Pidana lebih sempit cakupannya. Sebab dalam ganti rugi acara pidana ini tidak membuat alasan lain selain yang ditentukan pada Pasal 77 dan 95 KUHAP, sehingga pelanggaran terhadap norma masyarakat tidak dapat dijadikan alasan untuk memohon ganti rugi lewat sidang praperadilan. Untuk jelasnya alasanalasan yang dapat diajukan untuk minta ganti rugi dalam sidang praperadilan adalah sebagai berikut di bawah ini:

Pasal 77 ayat b Pengadilan Negeri berwenang untuk memeriksa dan memutuskan, sesuai dengan ketentuan yang diatur dalam Undang-Undang ini tentang ganti kerugian dan atau rehabilitasi bagi seorang yang perkara pidananya dihentikan pada tingkat penyelidikan dan penuntutan. (KUHAP,1994:35)

Adapun maksud penghentian penyidikan dalam ketentuan pasal tersebut diatas sebagai alasan permintaan ganti rugi dalam sidang praperadian bilamana oleh penyidik terdapat alasan-alasan sebagaimana ditentukan dalam pasal 109 ayat (2) KUHAP. Sedangkan maksud penghentian penuntutan yang dilakukan oleh penuntut umum, hal ini sebagaimana ditegaskan dalam pasal 140 ayat (2) butir a KUHAP

Sebagaimana ditegaskan $M$ Yahya Harahap, dalam bukunya Pembahasan Permasalahan dan Penerapan KUHAP menyatakan bahwa maksud atau pengertian dihentikan demi kepentingan hukum adalah: Bahwa penghentian atas dasar alasan demi hukum pada pokoknya sesuai dengan 
alasan-alasan hapusnya hak menuntut dan hilangnya hak menjalankan pidana yang diatur dalam bab VIII KUHAP, sebagaimana yang dirumuskan dalam :

a. Pasal 76 tentang nibis in idem.

b. Tersangka meninggal dunia (Pasal 77)

c. Kadaluarsa Pasal 78.

(1994:154-155)

Mengenai penghentian penyidikan dan penuntutan Menteri Kehakiman dalam keputusannya tanggal 10 Desember 1983 Nomor M. 14-PW.07.03 Tahun 1983 memberikan petunjuk sebagai berikut. Dalam hal penyidik menghentikan penyidikan sebagaimana dimaksud dalam pasal 109 ayat (2) dan penuntut umum menghentikan penuntutannya sebagaimana dimaksud dalam pasal 140 ayat (2) KUHAP selin harus memberitahukan kepada pihak tersangka atau keluarganya atau penasehat hukumnya juga kepada saksi pelapor atau korban.(P.A.F.Lumintang,

Lamintang, 1984:278)

. Alasan lain yang menjadi pertimbangan untuk menuntut ganti rugi yang dikenal dalam ketentuan hukum acara pidana, adalah sebagaimana ditegaskan pada pasal 95 Kitab Undang-Undang Hukum Acara Pidana. Joko Prakoso mengatakan bahwa perintah penangkapan tidak dapat dilakukan dengan sewenang-wenang tetapi ditujukan kepada mereka yang betul-betul melakukan tindak pidana. Sedangkan penangkapan dimaksud dalam pasal 17 KUHAP, dapat dilakukan untuk paling lama satu hari (pasal 19 ayat (1)). (,1984:99)

Selanjutnya mengenai penahanan juga tidak terlepas dari penentuan syarat yang harus dipenuhi, yaitu sebagaimana ditentukan dalam Pasal 21 ayat (1) KUHAP:

Perintah penahanan atau penahanan lanjutan dilakukan terhadap seorang tersangka atau terdakwa yang diduga karena melakukan tindak pidana berdasarkan satu bukti yang cukup, dalam hal adanya yang menimbulkan kekhawatiran bahwa tersangka atau terdakwa akan melarikan diri, merusak atau menghilangkan bukti atau mengulangi

pidana.(KUHAP,1984:15)

Dapat simpulkan bahwa untuk mengajukan ganti rugi dalam proses peradilan dimana hakim praperadilan: "Hanya dapat menetapkan suatu ganti rugi atas suatu penangkapan, penahanan serta penuntutan yang dianggap tidak syah, dan dapat diperluas dengan penetapan ganti rugi terhadap adanya tindakan yang lain, dimana dalam penjelasan pasal 95 ayat (1) ditafsirkan sebagai suatu kerugian yang ditimbulkan oleh upaya paksa lainnya seperti penggeledahan surat-surat" (Loebby Luqman,1984:75).

Pemeriksaan terhadap ganti kerugian sebagaimana disebutkan pada ayat (4) mengikuti acara praperadilan menurut pasal 95 KUHAP tersebut dibedakan antara:

a. Tuntutan ganti kerugian yang perkaranya tidak diajukan ke pengadilan dan;

b. Tuntutan ganti kerugian yang perkaranya diajukan ke pengadilan. (S. Tanusubroto, 1984:90)

Apabila diperinci seluruh uraian yang dapat dijadikan sebagai alasan untuk mengajukan ganti rugi, maka dapat dibagi ke dalam beberapa alasan:

a. Mengenai ganti rugi disebabkan, penangkapan atau penahanan:

- Penangkapan atau penahanan secara melawan hukum.

- Penangkapan atau penahanan dilakukan tidak berdasarkan Undang-Undang.

- Apabila penangkapan/ penahanan dilakukan tidak mengenai orangnya (diskualifikasi in person). Artinya orang yang ditangkap/ ditahan terdapat kekeliruan, bukan dia. Namun demikian tetap juga dia ditahan, dan kemudian benar-benar teranyata akan kekeliruan penangkapan/ penahanan itu.

b. Ganti rugi akibat penggeledahan/ penyitaan.

- Tindakan memasuki rumah secara tidak syah menurut hukum (tanpa perintah dan surat izin dari Ketua 
Pengadilan).

Harahap, 1984:44)

Lebih lanjut ditegaskan bahwa "Ganti kerugian oleh negara ini secara teknis lebih merupakan suatu pelayanan pembayaran kesejahteraan". (Arif Gosita,1986:31), sebagaimana dinyatakan oleh Sudarto bahwa: " Apabila ditinjau dari segi pencantumannya di dalam aturan KUHAP, maka ini merupakan suatu kemajuan apabila dibandingkan engan "Het Herziene Inlandesch Reglement atau HIR" (Staatsblad Tahun 1941 Nomor 44). Hal ini mencerminkan adanya kemauan untuk meringankan kepedihan dan penderitaan manusia adanya pengakuan mengenai hak dan kewajiban azasi manusia yang harus dikembangkan dan dipertahankan" (Sudarto, 1983:76).

\section{Proses Pemeriksaan Tuntutan Ganti Rugi}

Proses dalam persidangan praperadilan.

1) Pengajuan Tuntutan Ganti Rugi Sebagaimana dinyatakan dalam ketentuan pasal 95 ayat (2) dan ayat (3) KUHAP secara jelas ditentukan siapa-siapa yang mempunyai hak untuk mengajukan tuntutan ganti rugi oleh tersangka atau ahli warisnya atas penangkapan atau penahanan atau tindakan lain tanpa alasan yang berdasarkan Undang-Undang atau karena kekeliruan mengenai orangnya atau hukum yang diterapkan.

2) Tenggang Waktu Pengajuan

Mengenai penentuan batas waktu untuk mengajukan tuntutan slah satu ganti rugi, hal ini tidak diatur secara tegas dlam UndangUndang Hukum Acara Pidana baik pada pasal 95 maupun 96, sehingga untuk memperjelas penentuan batas waktu ini terpaksa dicari dalam aturan lain sebagai peraturan pelaksanaannya. Karena jika dilihat dari arti pentingnya masalah penentuan batas waktu pengajuan ganti rugi, hal ini jelas diperlukan sebagai salah satu patokan untuk menemukan kepastian hukum. Pentingnya menetapkan suatu batasan pengajuan masalah ganti rugi ini, lebih lanjut M. Yahya Harahap, menyatakan sebagai berikut di bawah ini:
Penentuan tenggang waktu sangat penting artinya bagi terbinanya kepastian hukum, sekalipun tuntutan ganti kerugian merupakan hak yang diberikan UndangUndang kepada tersangka atau terdakwa tentu perlu membatasinya dalam waktu yang tertentu adalah tidak layak untuk memberi kesempatan yang tidak terbatas bagi yang berkepentingan untuk mengajukan tuntutan ganti kerugian. Hal ini jelas mengaburkan kepastian hukum. (M.Yahya Harahap, 1984:551)

Maka atas dasar itu dikeluarkan suatu peraturan pelaksanaan untuk menentukan batas waktu, yaitu sebagaimana terdapat dalam Peraturan Pemerintah Nomor 27 Tahun 1983 tertanggal 1 Agustus 1983. Adapun peraturan pengajuan tuntutan ganti rugi dalam Peraturan Pemerintah tersebut di atas, secara jelas diatur pada Pasal 7 ayat (1) dan ayat (2), kemudian untuk menerapkan batas waktu tersebut lebih lanjut disarankan dalam penjelasan Pasal 7 Peraturan Pemerintah Nomor 27 Tahun 1983 menekankan bahwa: "Pembatasan jangka waktu pengajuan ganti kerugian dimaksud agar penyelenggaraan tidak terlalu lama sehingga menjamin kepastian hukum".

3) Aparat Pemeriksa Dan Putusan Ganti Rugi

Untuk kepentingan memeriksa dan memutus tuntutan ganti rugi tersebut dalam pasal 95 ayat (4) ditegaskan bahwa untuk memeriksa dan memutus perkara tuntutan ganti rugi tersebut pada ayat (1) Ketua Pengadilan sejauh mungkin menunjuk Hakim yang sama yang telah mengadili perkara pidana yang bersangkutan. Dan untuk pemeriksaan tersebut dilakukan dengan mengikuti secara praperadilan.

\section{Putusan Dan Penentu Besarnya Tuntutan Ganti Rugi}

Putusan sidang praperadilan atas suatu tuntutan ganti rugi yang diajukan oleh para pihak, biasanya dituangkan dalam suatu penetapan, yang mana hal ini sebagaimana ditegaskan dalam Pasal 96 Kitab UndangUndang Hukum Acara Pidana bawah: "Putusan pemberian ganti kerugian berbentuk penetapan (ayat1), kemudian 
penetapan sebagaimana dimaksud dlam ayat 1 memuat dengan lengkap semua hal yang dipertimbangkan sebagai alasan putusan tersebut (ayat 2)." (KUHAP,1984:44)

\section{METODE PENELITIAN Lokasi Penelitian}

Untuk mendapatkan data informasi yang dibutuhkan dalam penelitian ini, maka yang menjadi tempat penelitian adalah Pengadilan Negeri Padangsidimpuan karena data-data yang diperoleh dalam penelitian mudah untuk di dapatkan berdasarkan perumusan masalah yang diangkat dalam penelitian ini

\section{Pendekatan Penelitian Yang Digunakan}

Dalam penelitian ini penulis mempergunakan metode penelitian dengan membuat suatu hasil penelitian secara sistematis dan terinci berdasarkan fakta dan data yang akurat, yang diperoleh dilapangan penelitian. Adapun teknik pengumpulan data yang dipergunakan sebagai berikut:

1.. Penelitian Kepustakaan (Library Research)

Penelitian kepustakaan ialah dengan mengumpulkan data tertulis yang bersumber dari buku-buku literatur atau perpustakaan dan sumber-sumber tertulis lainnya yang erat kaitannya dengan masalah yang akan diteliti dan dibahas dalam penelitian ini.

2. Penelitian Lapangan (Field Research) Metode Field Research ini adalah metode yang dilakukan secara langsung kepada objek penelitian dilapangan, yang dalam hal ini adalah Kantor Walikota Padangsidimpuan.

\section{Jenis Penelitian Yang Digunakan}

Adapun jenis penelitian yang penulis gunakan adalah penelitian deskripsi, yaitu: penelitian yang bertujuan untuk mendeskripsikan secara sistematis, faktual dan akurat terhadap suatu populasi atau daerah tertentu, mengenai sifat-sifat, karakteristik-karakteristik atau faktor-faktor tertentu.

\section{Populasi dan Sampel \\ Populasi}

Menurut Suharsimi Arikunto bahwa populasi adalah : "Setiap penelitian senantiasa memiliki obejek penelitian dimana keseluruhan objek penelitian ini disebut sebagai populasi”.(Suharsimi Arikunto,1987:102)

Para Hakim yang berada di Pengadilan Negeri Padangsidimpuan, Advokat dan Para Jaksa pada Kantor Kejaksaan Negri Padangsidimpuan

\section{Sampel}

Selanjutnya penulis akan mengambil sampel terhadap penelitian ini, akan tetapi terlebih dahulu dikemukakan pengertian sampel seperti yang dijelaskan oleh Sudjana adalah : "Bagian dari populasi yang dipergunakan sebagai sumber data yang sesungguhnya dalam penelitian" (Sudjana,2008:25). Sesuai dengan kutipan tersebut di atas maka penulis akan mengambil sampel sebagai berikut yaitu seorang Hakim Pengadilan Negeri Padangsidimpuan

\section{Sumber Data}

Sebagai sumber data yang digunakan penulis dalam penelitian ini adalah sebagai berikut :

1. Data Primer adalah suatu data hasil dari pada wawancara pernulis dengan para responden

2. Data Skunder adalah dimana data ini diambil dari buku-buku atau literatur yang di dalam perpustakaan

\section{Teknik Pengumpulan Data}

Untuk mengumpulkan data penelitian penulis menggunakan tekhnik seperti berikut dibawah ini:

1. Interview (wawancara), yaitu mengadakan wawancara langsung dengan para responden yang telah ditentukan sebelumnya seperti Hakim, Panitera dan Pegawai Pengadilan Negeri Padangsidimpuan.

2. Studi dokumentasi, yaitu mengumpulkan serta mempelajari data-data yang 
berhubungan dengan masalah yang dibahas.

\section{Analisa Data}

Menurut pendapat Sudarto tentang Analisa Data adalah : "Mengolah data dengan menggunakan metode analisis yang dimaksudkan untuk mendapatkan pengetahuan ilmiah dengan mengadakan pemerincian terhadap objek yang diteliti dan menggabungkan beberapa pengertian diharapkan akan di dapatkan pengetahuan baru untuk pemahaman dan kejelasan arti yang dipahami" (1997:39-62), analisa data dalam rumusan penelitian ini menggunakan cara:

1. Induksi yaitu mengelola data dari fakta yang bersifat khusus untuk mengambil suatu kesimpulan pada hal yang bersifat umum

2. Deduksi yaitu mengolah data dari fakta yang bersifat umum untuk mengambil suatu kesimpulan pada hal yang bersifat khusus

\section{PEMBAHASAN}

Pentingnya Ganti Rugi Sebagai Upaya Perlindungan Hak Terhadap Korban

Penegasan lebih lanjut oleh Hakim

Pengadilan Negeri Padangsidimpuan, menyebutkan bahwa: adanya wewenang bagi para pihak yang didakwa untuk mengajukan tuntutan ganti rugi melalui lembaga peradilan adalah merupakan suatu prinsip penegakan hukum. Pentingnya keberadaan tuntutan ganti rugi melalui sidang praperadilan sebagai kontorol atas tugastugas aparat, khususnya aparat kepolisian dan kejaksaan, Hakim Pengadilan Negeri Padangsidimpuan menjelaskan bahwa jika dilihat dari pelaksanaan tugas penyidik, mereka punya hak untuk memaksa atau memakai sistim pemeriksaan inquisitoir sehingga kadangkala harus memakai upaya keras untuk mencari bukti-bukti, sedang bagi penuntut umum melakukan penuntutan disebabkan surat dakwaan adalah sebagai dasar pemeriksaan. Maka sejalan dengan itulah dengan adanya hak tersangka atau terdakwa untuk menuntut ganti rugi melalui sidang praperadilan, akan menjadikan aparat-aparat ini lebih berpikir dalam melaksanakan tugas-tugasnya. Jadi secara tidak langsung keberadaan atau pentingnya tuntutan ganti kerugian ini dapat dikatakan sebagai pengawasan. Bilamana penegasan tersebut di atas dijabarkan lebih luas untuk kepentingan peradilan pidana bahwa adanya hak melakukan tuntutan ganti rugi dapat dikatakan sebagai perwujudan azas keseimbangan, baik antara aparat dengan anggota masyarakat maupun antara sesama aparat itu sendiri. Hal ini sebagaimana dikatakan Hakim Pengadilan Negeri Padangsidimpuan bahwa dengan adanya hak bagi tersangka atau terdakwa untuk menuntut ganti rugi hendaknya para aparat penegak hukum harus sudh memulai berubah sikap mental dan pandangan ke arah cakrawala penegakan hukum dengan menempatkan kedudukan mereka bukan lagi semata-mata sebagai instrumen of power (alat kekuasaan) tetapi harus mampu memahami dan melihat diri mereka sebagai suatu kelompok aparat yang berfungsi sebagai pelindung masyarakat. Memperhatikan kepentingan tuntutan ganti rugi melalui penetapan sidang praperadilan sebagaimana diuraikan di atas, kiranya harapan tersebut tidak terlepas dari peranan hakim sebagai figur yang paling menentukan. Karena dengan kebebasan hakim ini diharapkan akan mampu mempertimbangkan setiap kepentingan tuntutan ganti rugi yang diajukan oleh para pihak-pihak, karena itu hakim harus mampu melaksanakan tugas dan tanggung jawabnya sebaik-baiknya. Disamping kepentingan hak menuntut ganti rugi melalui pemeriksaan sidang praperadilan di atas, juga masalah keberadaan tuntutan ganti rugi penting juga artinya untuk mengupayakan kewibawaan sistim peradilan. Karena dengan tersedianya bagi para pihak tersangka dan terdakwa untuk menuntut haknya atas kerugian secara materil, sekaligus akan dapat digunakan sebagai awal usaha melicinkan jalannya proses penerapan hukum baik saat pemeriksaan pendahuluan maupun saat pemeriksaan di sidang pengadilan. Yang mana hal ini 
sebagaimana dinyatakan Hakim Pengadilan Negeri Padangsidimpuan bahwa tuntutan ganti kerugian dengan permintaan melalui sidang lembaga praperadilan akan lebih memurnikan tata acara persidangan. Sebab dengan pemeriksaan penyidik serta tindakantindakan lain sat pengumpulan bukti-bukti akan dilaksanakan secara bersih menutut ketentuan undang-undang sehingg dengan kondisi demikian berita acara yang dikirim kehadapan sidangpun akan dapat difungsikan sebagaimana mestinya. Artinya tidak lagi asal dibuat demikian saja, tanpa mempertimbangkan hak-hak azasi.

Sebagai bukti masih kurangnya perhatian tentang pentingnya tuntutan ganti rugi sebagai suatu hak yang harus selalu diperhatikan, dimana hal ini tercermin dari pernyataan Hakim Pengadilan Negeri Padangsidimpuan bahwa keberhasilan tuntutan ganti rugi yang diajukan para pihakpihak yang berperkara tentunya sepenuhnya berada di bawah wewenang hakim, akan tetapi jika dilihat dari prakteknya kiranya aparat ini pun sepenuhnya dapat memahami keberadaan hak menuntut ganti rugi ini dalam proses peradilan perkara pidana. Saya katakan demikian karena hakim masih menganggap bahwa tuntutan ganti rugi yang diajukan tidak lebih dari sebagai memperlambat sidang saja atau suatu terobosan yang mengada-ada, sehingga setiap pengajuan tuntutan ganti rugi dirasa sebagai suatu pengungkapan kelemahan di pihak aparat, baik terhadap penyidik maupun terhadap penuntut umum. Berdasarkan pertimbangan jika di lihat dari kepentingan penentuan ganti rugi sebagai suatu hak untuk melindungi tersangka atau terdakwa dari segi material, ternyata aparat penegak hukum masih belum sepenuhnya dapat memahami arti pentingnya keberadaan di dalam proses peradilan. Oleh sebab itu keberadaan tuntutan ganti rugi melalui sdang praperadilan yang disediakan KUHAP sebagai salah satu upaya pengontrol masih menimbulkan masalah-masalah dalam perkembangan prakteknya.

\section{Alasan Permohonan Ganti Rugi Dalam Gugatan Pra Peradilan}

Setelah menguraikan pentingnya adanya hak menuntut ganti rugi melalui permohonan yang diajukan melalui lembaga praperadilan dalam suatu proses peradilan, kiranya aparat penegak hukum itu sendiri belum sepenuhnya dapat memahami dimana letak dan tujuan ganti rugi ini dbuat sebagai suatu hak berdasarkan KUHAP. Penulis katakan demikian karena sebagai aparat yang bertindak untuk menegakkan hukum secara menjamin terlindunginya hak-hak azasi manuia, khususnya dari segi perlindungan hukum yang bersifat material, tentunya dari merekalah seharusnya penegakan terjaminnya pelaksanaan tuntutan ganti rugi ini dapat difungsikan. Namun dalam prakteknya dasar atau alasan-alasan untuk melakukan suatu tuntutan berupa permohonan ganti rugi disebabkan adanya tindakan-tindakan aparat yang tidak berdasarkan undang-undang, masih saja kurang mendapat perhatian dari hakim yang memeriksa tuntutan ganti rugi tersebut. Karena sebagaimana dinyatakan hakim Pengadilan Negeri Padangsidimpuan bahwa sebagian besar penolakan tuntutan ganti rugi yang diajukan lewat sidang praperadilan disebabkan alasan dan pengajuan. Dimana para pihak baik tersangka atau terdakwa maupun penasehat hukumnya dalam mengajukan tuntutan ganti rugi ini hanya bermohon saja, sedangkan alasannya kurang disebutkan secara jelas dan pasti. Sehingga dengan kondisi tidak ada dasar bagi hakim untuk mempertimbangkannya, lebih lanjut hakim Pengadilan Negeri Padangsidimpuan menjelaskan sebagai berikut di bawah ini:

1. Penangkapan Yang Tidak Syah

Penangkapan ini adalah sebagai alasan yang pertama dimana dalam penangkapan ini hakim harus melihat beberapa persyaratan untuk menangkap apakah telah dilaksanakan atau tidak. Memang jika dilihat dai ketentuan undang-undang bahwa penangkapan yang tidak syah adalah apabila tindakan penangkapan tersebut tidak memenuhi alasan, jadi untuk menguji apakah alasan ini benar atau tidak disini perlu diperlukan 
penguraian yang jelas dan tegas oleh pedoman ganti rugi.

2. Penahanan Yang Tidak Syah

Sehubungan dengan masalah penahanan ini juga tidak terlepas dari pemeriksaan persyaratan saja, melainkan yang diperlukan untuk menjdi bahan pertimbangan hakim adalah pelaksanaan penahanan itu sendiri, apakah memang diperlukan serta telah dilaksanakan sesuai dengan ketentuan Undang-Undang Hukum Acara Pidana. Serta apakah jangka waktu yang telah ditentukan sesuai dengan batas maksimal yang dibenarkan.

3. Tindakan Lain Tanpa Alasan Hukum

Adapun tindakan lain yang tidak beralasan hukum maksudnya tindakan yang dilaksanakan pemeriksaan pendahuluan, misalnya seperti pemasukan rmah untuk mengadakan penggeledahan atau penyitaan. Yang mana saat mengadakan tindakantindakan tersebut pihak yang disita merasa dirugikan dengan adanya kerusakankerusakan yang diperbuat aparat. Maka untuk kepentingan ini hakim akan memerksa sejauh mana kebenaran pernyataan pengrusakan tersebut.

4. Dituntut dan Diadili Tanpa Hukum

Sebagai alasan keempat yang dapat dijadikan sebagai dasar tuntutan ganti rugi, hal ini termasuk kesalahan dan kekeliruan mengenai orang atau hukm-hukum yang diterapkan. Yang mana dalam keadaan seperti ini hakim akan mempertimbangkan kebenaran pengaduan terdakwa lewat sidang praperadilan, apakah kebenarannya dapat dipertanggungjawabkan bahwa tersangka dan terdakwa telah dijatuhi hukuman tanpa alasan yang tidak didasarkan atas ketentuan undang-undang.

5. Penghentian Penyidikan Dan Penuntutan.

Alasan pengajuan ganti rugi lewat sidang praperadilan disebabkan adnya penghentian penyidikan dan penghentian tuntutan, disini hakim aka memerksa kebenaran aparat untuk menghentikan penyidikan dan penuntutan. Karena sebagaimana yang ditegaskan dalam aturan Undang-Undang yang berlaku, bahwasanya melakukan penghentian penyidikan dan penuntutan bukanlah sesuatu yang mudah untuk dilakukan.sebab selain harus adanya pemberitahuan kepada para pihak yang mengadu, juga penghentian tersebut harus pula disertai dengan adanya alasan-alasan yang jelas, untuk apa dan kenapa dilakukan penghentian terhadap penyidikan maupun terhadap penuntutan. Berdasarkan seluruh uraian tersebut di atas kiranya sudah jelas bagaimana alasan atau dasar untuk mengajukan tuntutan kerugian ini kehadapan sidang praperadilan, dimana dari keseluruhan alasan-alasan yang disebutkan di atas bukanlah berarti hanya menyebutkan demikian saja, melainkan menyebutkan sebab-sebab mengajukan permohonan ganti rugi, juga harus jelas diruaikan kenapa sampai mengajukan tuntutan ganti rugi. Apabila ditinjau dari pekembangan praktek tentang penguraian alasan-alasan menuntut ganti rugi lewat sidang praperadilan ini. Lebih lanjut Hakim Pengadilan Negeri Padangsidimpuan menyatakan bahwa pemohon ganti rugi lewat sidang praperadilan kadang-kadang tidak dengan secara jelas dan tegas memaparkan kenapa sampai mengajukan ganti rugi, sebab jika dilihat dari kebiasaan selama ini, para pemohon hanya menyebut karena tidak sesuai dengan Undang-Undang, sehingga dia mengajukan ganti rugi tanpa penjelasan lebih lanjut secara rinci. Seperti misalnya tentang masalah penghentian penuntutan oleh Jaksa, dimana masyarakat sering mengajukan tuntutan ganti rugi lewat pemeriksaan sidang praperadilan bahwa pnuntut umum telah melakukan penghentian. Padahal setelah ditanyakan adakah sudah surat resmi yang mengatakan penghentian dari jaksa ternyata belum, jadi jelas kurang memahami bagaimana cara agar dapat dipertimbangkan jika seseorang mengajukan tuntutan ganti rugi ini. Mengenai apa yang ditegaskan Hakim Pengadilan Negeri Padangsidimpuan tersebut di atas, yang kemudian dikaitkan dengan perkembangan yang dilihat dalam prakteknya, ternyata ada benarnya, sebab tidak jarang seseorang yang mengajukan tuntutan ganti rugi melalui sidang praperadilan disebabkan adanya 
penghentian penuntutan, dimana para pihak, baik tersangka atau terdakwa kiranya asal mengajukan saja. dikatakan demikian sebab belum ada penegasan resmi dengan surat tentang penghentian penuntutan, oleh para pihak sudah terlebih dahulu mengajukannya. Sehingga setelah sampai kepada pemeriksaan sidang hakim terpaksa menyatakan bahwa tuntutan tersebut tidak dapat untuk diterima, dengan alasan kurang didasarkan atas alasan sebagaimana ditentukan undang-undang. Namun sekalipun demikian menurut pendapat Hakim Pengadilan Negeri Padangsidimpuan bahwa mengenai penyebutan alasan atau dasar mengajukan tuntutan ganti rugi ini sebenarnya tidak demikian perlu untk dijelaskan secara rinci dalam permohonan, sebab justru itulah tugas hakim untuk mempertimbangkanya lewat sidang peradilan. Sehingga jika seorang hendak mengajukan tuntutan ganti rugi lewat lembaga praperadilan cukup menunjukkan bukti, bahwa tindakan-tindakan yang dilakukan aparat tidak memenuhi persyaratanj undang-undang, dana apakah ini dapat diterima disinilah kegunaan pemeriksaan untuk mencari kebenaran. Berdasarkan seluruh uraian tentang alasan atau dasar untuk menuntut ganti rugi lewat pemeriksaan sidang praperadilan seperti dijelaskan di atas, kiranya sudah jelas bagaimana perkembangannya dalam praktek saat memeriksa tuntutan ganti rugi. Dimana secara umum dapat dinyatakan bahwa diantara para aparat yang terlibat dlam instrumen sebagai penegak hukum masih saja terdapat perbedaan pendapat.

\section{Realisasi Pelaksanaan Pemberian Ganti Rugi Pada Pengadilan Negeri Padangsidimpuan}

Sebagai perwujudan dari tuntutan ganti rugi melalui penetapan putusan sidang praperadilan adalah dengan permberian sejumlah ganti rugi kepada para pihak-pihak yang mengajukan tuntutan, yaitu dengan pemberian sejumlah uang sebagai imbalan atas kerugian yang diderita. Akan tetapi jika dilihat dari pelaksanaan dalam prakteknya masalah ini kiranya bukanlah sederhana menurut anggapan, melainkan ketentuan tata cara pembayaran ganti rugi ini masih berhubungan dengan instansi lain di luar pengadilan. Maka oleh sebab itulah jika ditinjau dari pelaksanaannya tidak berjalan sebagaimana diharapkan, atau dengan kata lain sekalipun ada penetapan praperadilan tidak berarti yang berkepentingan langsung mendapat pembayaran. Adapun langkah atau prosedur untuk merealisaskan pemberian ganti rugi ini. Lebih lanjut sebagaimana diperinci Hakim Pengadilan Negeri Padangsidimpuan seperti berikut di bawah ini. Bahwa tempo yang harus dinantikan bisa memakan waktu lama, sebab ketua Pengadilan Negeri terlebih dahulu membuat nota pengajuan kepada Departemen Keuangan. Sedangkan prosedur pihak Departemen Keuangan juga masih melalui prosedur yang telah ditentukan. Sehingga sangat menyulitkan bagi pelaksanaan pembayaran ini. Maka berdasarkan prosedur untuk meminta pembayaran terhadap pembayaran tuntutan ganti rugi yang telah ditetapkan oleh pengadilan tersebut benar-benar sangat rumit, sehingga sekalipun dalam kenyataannya pihak tersangka atau terdakwa sudah harus menerima haknya untuk menerima pembayaran tetapi realisasinya masih mengalami kelemahan. Maka oleh sebab itulah tidak jarang untuk menunggu penerimaan guang ganti rugi ini tidak jarang para tersangka atau rerdakwa masih harus berjuang semampu mungkin untuk menelusuri setiap prosedur yang ada. Memperhatikan jenjang atau prosedur untuk merealisasikan penerimaan tuntutan ganti rugi tersebut, kiranya masih harus mengalami pengorbanan yang tidak ringan. Maka sejalan dengan itulah Hakim Pengadilan Negeri Padangsidimpuan lebih lanjut menyatakan bahwa setelah ditetapkanpun ternyata para tersangka atau terdakwa tetap mengalami penindasan, dikatakan demikian karena sekalipun penetapan sidang praperadilan sudah menyatakan seseorang berhak untuk ganti rugi, ttapi masih mengalami ketidakpastian, baik mengani tata cara yang 
harus dilalui maupun korban waktu yang sedemikian lama untuk menunggu dicairkan. Maka sejalan dengan penegasan di atas kiranya dapat disimpulkan bahwa realisasi pembayaran ganti rugi belum sepenuhnya dapat berjalan dengan baik, sehingga tidak jarang persoalan yang seperti ini justru sangat menyulitkan pencarian keadilan. Demikian juga jika dilihat dari setiap perkembangan ternyata tuntutan ganti rugi melalui pemeriksaan sidang praperadilan, justru lebih sering ditolak daripada diterima dihadapan sidang.

\section{Hambatan-Hambatan Proses Pemeriksaan Tuntutan Ganti Rugi}

Dengan mempelajari seluruh

perkembangan pelaksanaan tuntutan ganti rugi melalui permohonan dalam sidang praperadilan, kiranya telah terungkap titik persoalan yang menjadikan acara tuntutan ganti rugi tidak dapat difungksikan dengan semestinya. Dimana secara garis besarnya dapat diutarakan bahwa pemberian ganti rugi pada wilayah hukum Pengadilan Negeri Padangsidimpuan, benar-benar masih mengalami hambatan-hambatan yang bersifat prinsip. Jika ditinjau dari keseluruhan, kiranya yang menjadi fakta utama penghambat tuntutan ganti rugi ini, jelas masih kurangnya kesadaran para aparat terdahap keberadaan tuntutan ganti rugi sebagai suatu hak yang dilindungi undangundang. Untuk jelasnya hambatan ini sebagaimana ditanggapi oleh Gabena Pohan, SH bahwa yang menjadi hambatan secara umum tentang pemberian atau proses pemeriksaan tuntutan ganti rugi, dimana kita sebagai aparat belum sepenuhnya menyadari apa yang terkandung di dalamnya. Dan persoalan ini tidak hanya ditimbulkan aturan undang-undang yang kurang jelas tetapi juga aturan pelaksanaannya yang belum ada, dan apabila hambatan-hambatan tersebut diperinci secara satu persatu dapat dibagi kedalam beberapa golongan seperti berikut ini:
1. Tingkat Kesadaran Aparat

Bahwa dengan diundangkannya

Undang-Undang Nomor 8 Tahun 1981 (Lembaran Negara 1981 Nomor 76) pada tanggal 31 Desember 1981 untuk menggantikan H.I.R. Stb, 1941 Nomor 44 sebagai hukum dalam proses beracara disidang pengadilan, sebagaimana diketahui bahwa salah satu yang menjadi dasar adalah dengan menempatkan hak-hak azasi manuia pada tempat yang semestinya. Oleh sebab itu dimana setiap proses peradilan pidana adalah merupakan kewajiban bagi setiap aparat untuk selalu menjadikannya sebagai pedoman dalam melaksanakan tugastugasnya. Seperti misalnya pada tahap pemeriksaan penyelidikan dan proses penyelidikan (termasuk penangkapan, penahanan, penggeledahan dan penyitaan) di sini benar-benar sangat prinsip untuk selalu mempertimbangkan masalah hak-hak azasi manusia ini. Dikatakan demikian karena dalam proses penyidikan dan penyidikan ini teradpat pembatasan atas hak-hak azasi manusia, oleh sebab itulah jika dilihat dalam perkembangannya tidak jarang aparat melakukan tindakan-tindakan paksa yang dapat berakibat kerugian bagi pihak lain. Maka sejalan dengan tindakan tersebut oleh aturan undang-undang diberikan hak bagi para tersangka atau terdakwa untuk mempergnakan haknya menuntut ganti rugi, yaitu melalui sidang praperadilan. Akan tetapi jika dilihat dari perkembangan prakteknya ternyata lembaga sidang praperadilan sebagai wadah untuk menuntut ganti rugi ini, keberadaannya belum dapat difungsikan sebagaimana mestinya untuk kepentingan penuntutan ganti rugi. Maka sejalan dengan itu oleh sebab lembaga praperadilan ini sebagai wadah penuntutan ganti rugi, menyebabkan ganti rugi yang dimohonkan di dalamnyapun terpaksa tidak diterima sekalipun sudah ada kerugian yang diderita. Jika dilihat dalam perkembangan praktek tentang alasan penolakan ganti rugi, tidak lain disbabkan seringnya penolakan hakim atas permintaan praperadilan. Dimana aparat masih menganggap bahwa adanya tuntutan ganti rugi melalui sidang praperadilan, tidak 
lain sebagai koreksi yang bersifat kritip terhadap negara dan justru bukan dianggap sebagai suatu hak untuk mempertahankan harkat dan martabat kemanusiaan.

\section{Peraturan Perundang-Undangan}

Sebagaimana telah ditegaskan dalam uraian yang terdahulu dimana ketentuan beracara yang berlaku dalam pemeriksaan praperadilan berlaku pula bagi pemeriksaan ganti rugi, yang mana hal ini sebagaimana ditegaskan dalam Pasal 95 ayat (5) Kitab Undang-Undang Hukum Acara Pidana bahwa "pemeriksaan terhadap ganti kerugian sebagaimana yang tersebut dalam pasal 95 ayat (4) mengikuti acara praperadilan". Akan tetapi bila ditelusuri lebih cermat kiranya aturan ini hanya semata-mata menyebutkan tantang cara sidang praperadilan, sedangkan untuk proses penuntutan ganti rugi tidak terdapat penjelasan lebih lanjut. Oleh sebab itu sekalipun sudahjelas ada krugian yang diderita para pihak (tersangka atau terdakwa) tetapi pemeriksaan sidang praperadilannya ditolak oleh Hakim menyebabkan secara otomatis juga tuntutan ganti rugi ini dianggap batal. Kemudian jika ditinjau dari tata cara pembayaran tuntutan ganti rugi, kiranya mengalami hal sama dengan proses pemeriksaannya. Dimana dasar hukum yang menjadi landasan tuntutan ganti rugi semua berpangkal pada Pasal 1 butir 22 dan Pasal 95 KUHAP, akan ditinjau dari hakekatnya sebenarnya bunyi kedua pasal bersamaan isinya dengan ketentuan Pasal 9 UndangUndang Nomor 14 tahun 1970 sebagaimana diubah dengan UU Nomor 45 Tahun 2009. Yang kemudian sebagai aturan Nomor 27 Tahun 1983 Pasal 7 ayat (2). Memperhatikan keseluruhan aturan-aturan hukum tersebut di atas kiranya yang menjadi hambatan adalah ketidak tegasan dalam pengaturan pembenahan tanggung jawab pembayaran ganti rugi, serta tidak jelasnya penentuan atau prosedur pengajuan tuntutan ganti rugi oleh tersangka atau terdakwa. Sehingga jika ditinjau dalam prakteknya sering menimbujlkan kesulitan, namun setelah mengalami perkembangan yang terjadi dikeluarkan pula Keputusan Menteri Keuangan tanggal 31 Desember 1983 No.
983/ KMK. 01/1983 yang menyatakan tanggung jawab pembayaran ganti rugi ada di pihak Departemen Keuangan. Akan yang menjadi kesulitan lagi alam aturan ini dimana penentuan pembayaran tersebut sangat menyulitkan para pihak, disebabkan banyaknya dan rumitnya prosedur yang akan dilalui, sehingga tidak jarang pembayaran ganti rugi hanya sampai pada penetapan saja. sedangkan realisasinya tidak terwujudkan dalam prakteknya sebagai perwujudan pelaksanaan aszas peradilan yang cepat, sederhana dan biaya murah.

3. Kurangnya Pengetahuan Hukum

Jika ditinjau dari sisi kesadaran hukum kiranya masyarakat sebagai pencari keadilan melalui lembaga sidang praperadilan sudah tidak ada masalah lagi demikian pula tentang pentuntutan ganti rugi sudah disadari bahwa itu merupakan hak yang disediakan undangundang untuk mempertahankan diri. Serta sudah pula diketahui kemana tujuan yang akan dicapai dengan adnaya tuntutan ganti kerugian di dalam proses peradilan pidana. Oleh sebab itu secara sepintas apa yang dicita-citakan dengan berlakunya KUHAP sekarang ini sudah hampir menemukan titik terang. Akan tetapi jika dilihat dari sisi yang lain yang masih merupakan hambatan adalah tentang perumusan alasan atau dasar pengajuannya kehadapan sidang praperadilan, dimana masyarakat (tersangka atau terdakwa) belum sepenuhnya mempunyai pengetahuan tentang masalah ini. Sehingga tidak jarang di dalam mengajukan tuntutan ganti rugi melalui sidang praperadlan hanya menyebutkan persyaratan Undang-undang yang telah dilanggar saja, tanpa lebih lanjut merumuskan atau menggambarkan akibatakibat yang diderita dari pelanggaran persyaratan tersebut.

4. Perbedaan Penafsiran Diantara Aparat

Ketergantungan masalah penegakan hukum dan perlindungan tegaknya jaminan hak-hak tersangka atau terdakwa melalui pemberian ganti rugi, jelas sepenuhnya tidak terlepas dari aparat sebagai pelaksana undang-undang itu sendiri. Karena bagaimanapun lengkapnya suatu aturan 
peundang-undangan dengan sendirinya akan meimbulkan ketidak adilan jika aparatnya sendiri tidak terdapat suatu kesamaan pandangan dalam menerapkannya. Jika dikaitkan dengan pelaksanaan pemberian jaminan berupa ganti rugi kepada tersangka atau terdakwa sebagai akibat tindakan aparat yang tidak sesuai dengan aturan hukum yang berlaku, kiranya prakteknya masih menunjukkan terjadinya perbedaan penafisiran untuk melaksanakan aturanaturan masalah tuntutan oleh Hakim Pengadilan Negeri Padangsidimpuan sebenarnya yang lebih utama untuk ditingkatkan dalam pelaksanaan tuntutan ganti rugi ini adalah kesamaan penafsiran. Karena jika hal ini terus terjadi maka inilah yang akan selalu menghambat jalnnya proses pemeriksaan tuntutan ganti rugi dalam prakteknya.

Untuk penegasan dari perkataan Hakim Pengadilan Negeri Padangsidimpuan tersebut di atas menambahkan bahwa dengan perbedaan penafsiran ini atas proses pemeriksaan dan pelaksanaan ganti rugi ini, hendaknya masih dibutuhkan suatu aturan pelaksana yang lebihmurah terarah. Karena dengan adanya aturan pelaksanaan nantinya akan dapat dijadikan sebagai pedoman untuk beracara di dalam sidang pengadilan, maupun untuk kepentingan pelaksanaan pemberian ganti rugi sendiri. Berdasarkan keseluruhan hambatan-hambatan yang penulis utarakan dalam penulisan ini, kiranya merupakan suatu persoalan yang ering menjadikendala di saat menyidangkan suatu tuntutan ganti rugi melalui sidang praperadilan. Maka dengan kondisi demikian masalah ganti kerugian ini di dalam prakteknya khususnya pada Wilayah Hukum Pengadilan Negeri Padangsidimpuan perlu mendapat perhatian, penulis katakan demikian karena mengingat kepentingan ganti rugi itu sendiri bagi tersangka atau terdakwa yang memang ditujukan untuk memberi perlindungan dalam bentuk material. Namun demikian sebagaimana ditambahkan Hakim Pengadilan Negeri Padangsidimpuan bahwa sekalipun pada kenyataannya masalah ganti rugi ini dalam bentuk material, tetapi hendaknya bagi aparat penegak hukum janganlah meninjau dari sisi itu saja Melainkan makna yang terkandung dalam pemberian ganti urgi itu yaitu merupakan suatu perwujudan bahwa dalam sistim peradilan di Indonesia benarbenar hak-hak azasi manusia itu cukup mendapat penghargaan. Mengenai apa yang ditegaskan Hakim Pengadilan Negeri Padangsidimpuan tersebut di atas ada hubungannya dengan tujuan berlakunya KUHAP untuk menggantikan HIR adalah sangat tepat sekali. Penulis nyatakan demikian tidak lain mengingat bahwa hak-hak azasi manusia (tersangka atau terdakwa) adalah merupakan dasar bagi diberlakukannya KUHAP sebagai Hukum Acara Pidana. Maka oleh sebab itulah tegaknya pemberian tuntutan ganti rugi dalam pelaksanaan dan penerapan KUHAP sekarang ini, jelas tidak terlepas dari kenyataan bahwa negara Indonesia merupakan negara yang didasarkan atas hukum (rechtsstaat) dan bukan didasarkan aztas kekuasaan belaka (machsstaat). Maka dengan demikian pelaksanaan ganti rugi ini masih belum menunjukkan kekuatan, sebagai salah satu dari upaya perlindungan bagi pelanggaran atas hak-hak azasi manusia.

\section{Kesimpulan Dan Saran Kesimpulan}

a. Bahwa dasar atau alasan bagi hakim dalam menetapkan ganti rugi sebagai akibat putusan praperadilan adalah kerugian moral atau material yang diderita oleh tersangka/terdakwa karena akibat upaya paksa yang dibuktikan berdasarkan keyakinan hakim.

b. Bahwa pada dasarnya sebagai penghambat kurangnya pelaksanaan ganti rugi dalam prakteknya, adalah disebabkan belum adanya bentuk secara khusus yang mengatur ketentuan proses pengajuan tuntutan ganti rugi.

\section{Saran}

a. Bahwa untuk kepentingan perlindungan hukum atas hak-hak tersangka atau terdakwa, kiranya penggunaan upaya 


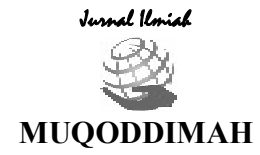

pemberian ganti rugi melalui para pihak perlu segera mendapatkan perhatian aparat.

b. Untuk lebih meningkatkan pemanfaatan serta mempermudah pedoman ganti rugi lewat tuntutan melalui sidang praperadilan, perlu diadakan atau dibentuk suatu aturan khusus mengenai tata cara pengajuannya. Dengan tidak mengurangi aturan untuk pelaksanaan azas peradilan cepat dan biaya murah yang dicanangkan berlakunya KUHAP.

\section{DAFTAR KEPUSTAKAAN}

Arif Gosita, Masalah Perlindungan Anak, Sinar Grafika, Jakarta, 1986

Joko Prakoso, Masalah Ganti Rugi Dalam KUHAP, Bina Aksara, Jakarta, 1989

Loebby Loqman, Kapita Selekta Tindak Pidana di Bidang Perekonomian, Data Com, Jakarta, 2002

M.Yahya Harahap, Pembahasan Permasalahan dan Penerapan KUHAP, Raja Graindo, Jakarta, 1999

P.A.F. Lumintang, Lamintang, Kitab UndangUndang Hukum Acara Pidana Dengan Pembahasan Secara Yuridis Menurut Yurisprudensi dan IImu Pengetahuan Hukum Pidana, Sinar Baru, Bandung, 1984

R. Subekti, dan R. Tjitrosudibio, Kitab Undang-Undang Hukum Perdata, Pradnya Paramita, Jakarta, 2001

Sumadi Suryabrata, Metodologi Penelitian, Rajawali, Jakarta, 1993

S.Tanusubroto, Peranan Praaperadilan Dalam Hukum Acara Pidana, Alumni, Bandung, 1984
Sudarto, Hukum Pidana dan Perkembangan Masyarakat, Sinar Baru, Bandung, 1983

Suharsimi Arikunto, Pengantar Prosedur Penelitian Suatu Pendekatan Praktik, Bina Aksara, Jakarta, 1987

Sudjana, 2008, Metodologi Penelitian Sinar Grafindo, Grafindo, Jakarta, 2008

Sudarto, Metodologi Filsafat, Raja Grafindo Persada, 1997

Wirjono Prodjodikoro, Tindak-Tindak Pidana Tertentu, Eresco, Jakarta, 1980

Undang-Undang Nomor 48 Tahun 2009 Tentang Pokok-Pokok Kekuasaan Kehakiman,

Undang-undang Menteri Hukum dan Hak Asasi Manusia Republik Indonesia, 2009

Undang-Undang Dasar 1945, Indonesia Tera, Yogyakarta, 2008

KUHAP, Bumi Aksara, Jakarta, 1994

Peraturan Pemerintah Nomor 27 Tahun 1983 tentang Peraturan Pelaksana UU Nomor $8 \quad$ Tahun1981, Mensegneg RI, Jakarta, 1983 